\title{
Why 'Where' Matters: Exploring the Role of Space in Service-Learning
}

\author{
Megan Snider Bailey \\ The University of Alabama
}

This article culminates a two-year qualitative case study concerning how 33 students in a servicelearning course understood poverty as they prepared taxes for low-income families through the IRS's Volunteer Income Tax Assistance program. Because the tax site communities are seen as community partners in their own right, this research takes up Clark \& Young's (2005) and Siemers, Harrison, Clayton, \& Stanley's (2015) call to attend to the spatial effects of service-learning. It finds that the 'where' of service-learning matters as deeply as the 'what' given that service placements - particularly in hometowns or college communities cause students to interact in the spaces served in new ways. Service-learning encourages an unpacking of the ways that inequalities are mapped onto particular spaces (e.g., "ghettos," "safe neighborhoods," etc.). By attending to conceptualizations of communities, service-learning helps students tease out spatial inequities and power structures at work in those communities.

From early January through mid-April, college students from The University of Alabama serve in Alabama's poorest neighborhoods - both rural and urban - in an effort to combat gross injustices pervading the for-profit tax industry that targets working poor taxpayers qualifying for the Earned Income Tax Credit (EITC; Robertson, 2014). Impact Alabama, which is a nonprofit that develops service-learning and leadership development projects for college students (ImpactAmerica.com/Alabama/), operates a service-learning initiative that "trains college, graduate, and law students to provide free tax preparation services and opportunities for savings and economic improvement to lowincome, working families - especially targeting those eligible for the Earned Income Tax Credit" (Impact America, 2016). During 2016, more than 675 students helped 10,598 taxpayers and families; the program saved these families an estimated $\$ 4.2$ million in fees associated with commercial tax preparation and secured the families \$20.4 million in tax refunds (Impact America).

Students serving through an Honors course on poverty and justice act as tax site greeters, who welcome taxpayers and answer any questions they might have about preliminary paperwork; they also prepare income tax returns for families making up to $\$ 52,000$ or working individuals earning $\$ 20,000$ or less. Students complete all the basic elements of the tax return, including personal and dependent information, W-2s and other income documents, and common exemptions and credits, such as the Child Tax Credit. Campus Fellows, who are advanced certified students who participated in the servicelearning experience in a prior year, complete remaining requirements for the tax return, including itemization or retirement income forms, before the return is reviewed for a quality check. The entire process lasts about an hour. After meeting IRS Volunteer Income Tax Assistance (VITA) requirements to serve, college students in the service-learning course and those who return as Campus Fellows help curb the reliance in low-income communities on paid tax preparers (distinguished from CPAs) who often employ predatory practices to make profits (e.g., Progressive Policy Institute, 2016).

To meet the needs across the region, students participating in the service-learning course travel across the state to ensure that many of the most vulnerable citizens have access to free, high quality tax preparation. The tax sites are located in libraries, churches, and community centers within the neighborhoods where most of the taxpayers live; generally these are neighborhoods in which a high percentage of residents qualify for the EITC and where paid tax preparers are most concentrated (Progressive Policy Institute, 2016). Many of the students enrolled in the course are in-state students who travel to their home communities to prepare taxes. Out of state students travel broadly across the state to serve; in the process, they become more acquainted with the realities of the region's poor and the nuances of Southern life. In addition, all students in the service-learning course have the opportunity to serve within their college town, an experience that causes many to understand the town and its relationship to campus in more nuanced and interconnected ways. The combination of course content on the realities of poverty, its structural and individual roots and effects, and the servicelearning experience at VITA tax sites across the 
state causes many students to complicate their assumptions of poverty and develop understandings of civic responsibility grounded in reciprocity and connection to place.

This article is a qualitative study of the servicelearning course described above conducted across the spring 2015 and 2016 semesters. The research demonstrates the way that space/place shapes students' sense of geographic and cultural possibility within communities with which they are familiar. Many of the students who have the opportunity to return to their hometowns to serve find that they are unfamiliar with the neighborhoods where the free tax sites are located. Students find that their perceptions of poverty and what it means to be an engaged community member become complicated when serving in areas that were once absent or marginalized in their understanding of their hometowns. Further, students who serve in their college town express a deeper sense of responsibility to the community that allows for their education. This research seeks to untangle the relationship between space/place and service in order to explore the way that service-learning experiences can be more attentive to the places that produce those experiences and the power structures at work there.

\section{Literature Review}

Service-learning's pedagogic roots are often linked to Dewey's $(1900,1916)$ emphasis on democratic citizenship fostering connections within communities (e.g., Giles \& Eyler, 1994). With the exception of Clark and Young's (2005) and Siemers, Harrison, Clayton, \& Stanley's (2015) foregrounding of the places where service occurs, the notion of community has generally concerned interactions between individuals. The significance of the community to service-learning pedagogy has primarily focused on the people within communities rather than the educative value of places in their own right. Milofsky and Flack (2005) even note that place can be a burden when teaching engaged citizenship since "service-learning in the local community has an important, but somewhat limited impact because students return to the campus and its social and cultural life at the end of the day" (p. 168). They rightly suggest that the experience of service can seem like an excursion rather than a necessarily perspective-shifting process.

Thus, the focus on community in service-learning has largely been with community problems rather than the spatialization of community itself (Harvey, 1973/1993). This research takes up Clark and Young's (2005) and Siemers et al.'s (2015) call to employ the spatial in theorizing about service- learning efforts and attends to critical geography's desire for an education steeped in place and space in order to understand social processes and inequities. For example, a service-learning project in a rural school might consider not just the experiences of the students in the school but also how the very location of the school and geography of the community impact the educational clime or access to medical care. Just as the location of a grocery store affects access to nutrition and proximity to a chemical factory can cause a spike in asthma, where you are located matters because many inequities play out in any given space. When students embark on service-learning experiences without attending to the particular concerns of the place they are serving in, one way of understanding power dynamics in the community remains invisible.

For the purposes of this study, space/place are intertwined to suggest that the way that we locate ourselves within communities has consequences. Where you are located is no longer a mere background for interactions; space is reconceptualized as productive of social relations. For example, Helfenbein (2010) suggests that space produces social relations that educators must engage seriously. Place, meanwhile, evokes the local where the meaning-making experience of serving in community occurs (Somerville, 2010). With regard to service-learning, Siemers et al. (2015) note:
Being a citizen is being a citizen of place. Place is both a point on a map and a framework, a site of civic involvement and civic innovation, and a lens through which we, seeing from and through a place, can critically interpret and re- imagine the world. (p. 103, emphasis in orig- inal)

Joining space/place denotes that the experience of service-learning is both intimately local (to individuals, classes, and communities), yet it is also acting upon and within a web of power relations that can be mapped in order to understand the consequences those power relations bear on the space/place.

Because service-learning involves experiential learning beyond the classroom, teaching via service-learning necessitates asking: What does it mean to cross borders, to pass through, to enter in, to leave? Students engaging in service-learning are affected by, even as they are affecting, communities. Taylor and Helfenbein (2009) argue that students possess multiple maps of communities that they use in order to make sense of identities and power structures. These maps are both literal, in the sense of redlined neighborhood zones and food deserts, and imagined, as happens when students sense an unarticulated discomfort in particular 
spaces/places. Yet because these maps have very real economic and political consequences, servicelearning efforts concerned with developing an engaged citizenry must remain attentive to GibsonGraham's (2003) "ethics of the local" by attending to the particularities of the communities served. While Clark and Young (2005) call attention to the way that space/place shapes service-learning experiences and the communities in which those experiences occur, there is still a need for exploring the way that particular communities prompt particular learning experiences. Could service-learning experiences attending to space/place happen anywhere, or do community sites possess particular contexts that make possible particular mappings and re-mappings on the part of students engaging in service-learning?

Beyond Clark and Young's (2005) and Siemers et al.'s (2015) call for place to be studied in service-learning, there have been limited efforts to engage space/place in the theorization of servicelearning. In one example, Curry, Heffner, and Warners (2002) call for service-learning pedagogy to account for place in addition to people by noting that the campus community and the larger college town are necessarily entwined. Their suggestion stems from a service-learning project concerning on-campus wetlands impacted by community water drainage practices; however, despite this narrow scope, their call can also be read as evoking social constructionism in understanding the geography of communities. Hayes and Cuban (1997) similarly invest in the notion of place and servicelearning when they suggest that the metaphor of border crossing could apply to service-learning pedagogy in that entering new places in order to serve can cause students to reconceptualize relationships and identities. However, service-learning scholars must be attentive to the ways that certain peoples can cross borders and enter new terrains while others necessarily remain on the margins. When students enter a low-income community for temporary service projects, what does it mean for the community that they encounter?

Gruenewald's (2003) place-conscious pedagogy is useful here. He extends a focus on place to suggest that students must be deeply accountable to the places where service occurs. Service-learning helps students orient themselves in their community, and communities should demand they be accountable. Gruenewald suggests that educational institutions necessarily encourage an insular culture, sometimes known as the "campus bubble." To neglect the places in which education occurs is to render invisible the geographic orientation of power and privilege. He suggests:
When we accept the existence of places as unproblematic - places such as the farm, the bank, the landfill, the strip mall, the gated community, and the new car lot - we also become complicit in the political processes, however problematic, that stewarded these places into being and that continue to legitimize them. Thus places produce and teach particular ways of thinking about and being in the world. They tell us the way things are, even when they operate pedagogically beneath a conscious level. (p. 627)

Instead of assuming that inequalities are a necessary starting point, service-learning should encourage an unpacking of the way that power is mapped onto particular spaces. The spaces/places of service-learning tend to be signified by metaphors which map onto underdevelopment. Lowincome communities become ghettoed spaces (Paperson, 2010) or rural ghosts (Kitchin, Gleeson, \& Dodge, 2013); in both metaphors, the spaces of low-income communities are absent in the imagination of outsiders, so that knowledge can be mapped upon the communities served with little concern for the lived onto-epistemologies that already exist in those communities. Gruenewald (2003) further stipulates that experiences of place should be complicated in that students may interact with and experience particular places in different ways. As will be demonstrated, the 'where' of service matters as deeply as the 'what;' students' conceptualizations of their role within communities are bound up with their conceptions of the place where they serve. Thus, service-learning seems well-suited to meet Soja's (1989) call for educators to make visible geography's role in political and economic inequalities.

\section{Methodology \& Methods}

This study began as an effort to document the reflective thinking process students underwent as they engaged in service-learning experiences at VITA tax sites. As with Swaminathan (2005), I was interested in ways that a particular service-learning experience collapsed spatial distance between campus and community and promoted transformative dialogues shaping students' understandings of their community. As a former student in a sister servicelearning course and a long-term tax preparer at a VITA tax site, I wanted to understand what it was about doing taxes - which most college students considered a boring, dreadful activity - that caused students in this service-learning course to reevaluate their understandings of poverty and their responsibility to their community. This research 
represents a facet of a two-year qualitative study toward that end.

During the 2014 and 2015 tax seasons (spring 2015 and 2016 respectively), 163 students participated in a service-learning course on poverty and justice ${ }^{1}$, which involved extensive service at VITA tax sites throughout the southeast U.S. With permission from The University of Alabama's Institutional Review Board and the course professor, all 163 students were invited to participate in the study, of which 33 consented. Study participants were representative of the overall class make up, but they tended to be more invested in the program, returning to serve as Campus Fellows at high rates in the following tax years. I engaged with these students in a case study that took place over the summer semester immediately after the students finished the service-learning course. Thus, the participants were all current students or immediate graduates. The participants came from different communities and served in different communities; however, they were primarily female and white, which is representative of the makeup of the class overall. Additionally, almost a fourth of the participants noted that they or a close family member had personally experienced poverty. Although the students shared the experience of learning to do income taxes and preparing tax returns for working families, they came to the tax sites with different understandings and expectations.

I conducted hour-long interviews with 12 of the 33 students; this ratio was expected given that many students were off campus for the summer break. The interviews were audio recorded, transcribed, and sent to the individual participants for their feedback. Additionally, written data included reflective journals kept throughout the course and essay responses meant to critically engage the students in analyzing the dominant narratives about poverty and their perceptions of poverty. These data sources were selected because they offered insight into the ways students' views developed during the service-learning course; written data were collected and analyzed for all 33 participants.

Data was analyzed using qualitative methods, including coding, reflective memoing, situational mapping, and continued conversations with some of the participants. The research involved first round coding that employed constructivist initial coding using thematic coding and gerunds to highlight the active interrelationship between the participant and her experience moving through the service-learning project (Charmaz, 2014). An Excel spreadsheet was used to code data. Codes included, among others: committing to community, mapping poverty, and locating privilege. Through- out the research process, I constantly engaged in reflective memoing, moving back and forth from topical analyses to theoretical insights. After the initial round of coding, I found that the data was rich with complexity. In all, initial coding provided over 4,000 individual data points to sift through. At its best, coding opens up and extends a way of thinking and being in the research. The danger in coding, of course, is that it makes a particular cut into the data and collapses ontological and epistemological complexity in a single word or phrase (e.g., Augustine, 2014; A. Kuntz, personal communication, November 18, 2015). While having thousands of individual codes was cumbersome to the research process, it allowed me to attend to the complexity that such a large qualitative study necessitates without demanding dialectical synthesis.

Clarke (2003) suggests that "situational analyses can deeply situate the research individually, collectively, social organizationally and institutionally, temporally, geographically, materially, culturally, symbolically, visually, and discursively" (p. 554). Thus, I turned to her use of postmodern grounded theory to map relationships and differences in the participants' experiences. Importantly, mapping engages a cartographic process in the mind; because mapping makes meaning of spaces, it necessarily involves interpretation and imagination on the part of the researcher (Deleuze \& Guattari, 1980/1987). Mapping should be highlighted as a powerful tool in that it allows the researcher to engage in the complexity and power relationships inherent in the data.

Historically, maps have been used to make claims about what is known in space and what remains to be known. Maps from antiquity end when the space that has been disciplined is charted; instead of definitive claims about what remains of the world, fantastical images of dragons and serpentine sea creatures rest on the margins of space that has been brought under control (e.g., Kitchin et al., 2013). While I was initially drawn to situational mapping as a way to make visible the experiences that the participants wrote and spoke about, it quickly came to feel appropriate given that the experience of service-learning asked students to map new meanings onto communities. As I situationally mapped the data, I remained attentive to the ways that students engaging in service-learning move through space in travelling to different communities to prepare tax returns. Just as I was mapping their data, I found that the students engaging in service-learning were similarly engaging in a mental cartographic process. Their language showed a heightened attention to the spatial and the power relations that it allows. It also suggested that servicelearning made possible for students new maps of 
communities than those that they drew from before taking part in the service-learning. Thus, I honed in on the spatial as the situation that I became most interested in within the data. I began to visually and theoretically explore the relationships between the situations of entering into familiar and unfamiliar spaces to engage in service. The maps pushed me to write through themes that seemed to exist simultaneously, such as the idea that geography acts as a sorting machine but also the concurrent desire to claim community. The concurrent themes both allowed for and conflicted with one another. Similar to the experience of Richardson and St. Pierre (2005), writing became a research method in that analytic memos allowed me to engage with the complexity in the maps and to decide which relationships were worth further exploration.

As I wrote, I found myself wanting to attend to the differing conceptions of place that are made possible by the intimately humanizing process of going over the year's financial documents with a complete stranger. There is an openness to vulnerability in that process. It necessarily shapes perspective; you cannot walk away from the experience of helping a single mother of three enter four W-2s into the tax software and apply for the Earned Income Tax Credit without reevaluating your stance on the people living on 'the other side of town.' Nor can you leave an experience in your hometown serving an elderly married couple who are dealing with rising medical bills and job loss without reevaluating your assumption that the people living in the urban center must be doing better than your family on the fringes. Doing taxes together maps the course of life over the past year, collapses the distance between strangers, and offers an opportunity for a conversation built on shared community. As I engaged in constant conversation with the data and the relationship between participants' stories of their experiences with the taxpayers they served, I found that this was the story that I wanted to tell. It is a story of service-learning that invests students in community in a way that shifts their understanding of responsibility to place.

\section{Findings}

At the outset of the semester, students understood the communities that they prepared to serve in through very bounded definitions. Before beginning the service, students identified the neighborhoods where the free tax sites were located through discursive markers such as "trailer parks," "run down" neighborhoods, and "dilapidated . . . houses." These markers were explicit, yet they seemed to indicate implicit assumptions about the spaces that they would soon serve. One student from a rural community suggested that these markers were indicators of poverty, which she described as typically represented as "a black single mother raising one or two children, living in a city." Stuart, another student in the service-learning course, said that his immediate assumption of impoverished spaces was "broken families, drugs, crime, poor quality of life, minimum wage jobs, and ghettos." Thus, the spatial markers were coded; passing by a homeless person or a heavily agricultural area helped students map expectations of the communities encountered (Dacheux, 2005). Poverty could be either urban or rural, but for students on the outset of their servicelearning experience, it was fixed and immediately recognizable.

Because this service-learning experience required students to serve at tax sites around the state, they necessarily crossed through manufactured borders that, to them, had previously contained poverty. Paula noted that her service-learning experience forced her to confront spaces of poverty beyond the passing "drive through." Her phrasing suggests that she, as a college student from a suburban area, could pass through certain spaces at leisure; though, of course, those who live there could not do the same. The necessity of entering into new spaces to be in the spaces - as opposed to passing through - required of students a conceptual shift in the way they understood themselves in relation to the space/place they served.

While serving at the tax sites, students began resisting rhetoric of deficit or blame; they turned instead to structural problems they saw in the communities they served (Shabazz \& Cooks, 2014). Carla said of the taxpayers she encountered, "They were really struggling, but it certainly wasn't from lack of effort." Blaire pointed out the "limited resources" that visibly stratified neighborhoods from those "in a higher tax bracket." Meanwhile, Andrea said:

I have come to realize that both hard work and chance affect our lives - that we do have control over our life's course in general, but that the playing field is not even, that some people face obstacles that deplete their hope and control more than others.

Drew pointed to structural causes of poverty that caused him to reevaluate his personal experience of financial hardship, noting that the service-learning experience caused him to realize "how important environmental factors were to inhibiting social mobility, something I had never struggled with, regardless of poverty being in my family's history." As a white student, he realized that his whiteness 
had helped insulate his family from geographic barriers, such as segregation and redlining, which helped maintain stratified communities.

Students also began to understand the effects of this stratification on the health of communities themselves. Blaire noted that even though she was serving at a tax site located just minutes from campus, "I had never been over to that side of town ... and neither had any of my older friends. It feels like a different town; I don't think people put much thought into what it's like. It's very split off." Prior to her service-learning experience, she understood college and community as isolated from one another rather than supporting one another in a reciprocal relationship. Jack further analyzed the systemic issues that combined to form geographic barriers containing the poor. After visiting a tax site in an unfamiliar town, he began synthesizing the knowledge he had garnered from class readings and discussions with what he observed in travelling to one of the tax sites. He wrote:

\begin{abstract}
A large portion of residents find themselves unemployed or underemployed, and anyone with the financial capability to leave does so, leaving the community with a limited tax base and terrible property values, which leads to underfunded public schools, which in turn inclines more people to move, and a vicious cycle is perpetuated.
\end{abstract}

He suggests that this phenomenon remakes oncethriving communities into "ghost[s] of [their] former sel[ves]."

While not logistically possible for many participants, those students who were able often travelled back to their hometowns to serve at local tax sites. This experience caused students to reevaluate their assumptions of parts of their hometown that they were not endemically familiar with. Malorie was a freshman from an upper middle class suburb outside a major urban area. Her city had experienced significant white flight during the second half of the twentieth century, resulting in a downtown that remained, until recent gentrification, largely abandoned. Upon serving at a tax site in her hometown's downtown area, Malorie remarked:

I had never really been to those places before, so it was just kind of eye opening I guess that this is happening so close to where I'm from. But I did get to have conversations with a few of [the taxpayers] about what parts they go to downtown. . . . I was like, 'Oh I know where that is,' so that was nice. . . . It was just like I don't think I'd ever been to that neighborhood. .. . It was kind of crazy. . . I guess when I think of the city and downtown, I think of bad types of like, you know, low-income, so I guess [how I think about the area] kind of stayed the same except now I have actual personal experience with them, so I know what I think of them and not, like, it's based off of what other people [said who] were like, 'Oh watch out. It's really dangerous down there.' Now I know.

Fulfilling her service-learning experience in her hometown opened Malorie to a more nuanced and empowering realization about space/place and its construction than she could have had at a service site that was chosen at random or for logistical convenience. She became steeped in local knowledge that helped her reimagine the downtown area and its inhabitants as working taxpayers rather than 'dangerous' people, which encouraged a more relational ethic of service in community (Ellis, 2007). This personal re-experiencing of space/ place helped Malorie imagine an alternative mapping of her hometown, which later empowered her to respond to her fellow citizens when she heard them invoking stereotypes about the dangers of the downtown space.

Jordan, a first-generation college student from a small, rural town, entered the service-learning course with a personal experience of poverty and life on the periphery. Jordan returned to his hometown multiple weekends throughout the semester to help meet an overflowing need for free tax preparation in the area. Jordan said:

The tax site was on the other side of downtown
where I have actually never been. It looked
much different from where I spent most of my
time in town. I felt that it was humbling to be
at [my hometown's] tax site. I met people from
different backgrounds that I would never have
interacted with unless through this program.
It was shocking to see how low some of the
peoples' incomes were in my hometown. The
city, to me, always seemed like a city for the
'rich people.' To see that [my hometown] had
poverty too was enlightening.

Though Jordan had personally experienced poverty, he still entered the service-learning experience with a flattened map of what poverty was and where it was located (Dacheux, 2005). His experience of serving people that he had previously assumed to be from the wealthy part of town forced him to rearticulate an understanding of the spatial dimensions of poverty. His familiarity with the area demanded that he pay closer attention to the spatial embodiment of those taxpayers with whom he worked. After serving at another tax site, Jordan observed that when serving in a less familiar location, the service requirement "feels like volunteering, but in 
my hometown it felt like more since I was so familiar with the area." Thus, the heightened attention to the local prompted Jordan to have a more engaged takeaway in his conceptualization of space/place and the impact he had on the community served. Rather than merely donating time, Jordan's experience serving in his hometown felt like a deeper engagement linked to civic responsibility.

For logistical reasons, only a subset of the students in the service-learning course were able to commute to their hometowns for this service-learning course. However, a much broader swath of students were able to serve at one of the largest tax sites, which is located near campus. Though the local tax site is just under four miles from the university, many of the students were extremely unfamiliar with the service site and surrounding neighborhood.

One student, Daniel, served at the tax site adjacent to campus and noted that he lived off campus a few blocks away. However, he felt that he had previously had very limited engagement with his fellow community members. Daniel explained:

For the most part, it's like, you know, you're either on campus or I'm at my apartment, or you're at parts of town like [the new outdoor shopping complex] or like areas that are a little nicer when you're a student. So you know being at ... the off-campus tax site, especially since it's kind of in a part of town that you're not normally in, it helped me see and understand where I'm living more. Like understand[ing] the majority of people in town aren't involved with the college.

Daniel felt that his interactions with taxpayers at the off-campus tax site helped enlarge his map of his community while in college. Places that he had previously merely passed through in his drive from the space of his apartment to that of campus now demanded attention and engagement (Clark \& Young, 2005). He continued:

Knowing that, 'Oh these are my neighbors;' I need to care for my neighbors because they're helping us and our city run in so many ways. Being new to [the campus community], I really enjoyed meeting the people who make up the community to which I live. I think prior to [the first day at the service-learning site], my perception of the town was the majority white, mostly upper middle class environment that makes up the university and the church I'm a part of. It was thus great to meet and get to hear stories from people who make up a large portion of the community that I otherwise have little to no interaction with. [It] really helped me more properly grasp the place that I call home.
Daniel's interactions with taxpayers made possible new mappings of his college town. Prior to his service-learning experience, Daniel's understanding of his college town was limited to campus and the places that he socialized off campus (e.g., his apartment and shopping centers). Despite living adjacent to the tax site neighborhood, that area had been largely invisible to him when his interaction was one of merely passing through. Upon engaging in the space of the tax site via the service-learning experience, Daniel's understanding of the space shifted to one of reciprocal relationship and communal responsibility.

Carrie, who also served at the tax site near campus, experienced a similar desire to imagine a new role within the space of her college town. She said of poverty in the area:

I take so much from this area. People from this
area work at the schools . . . or the shops that
I shop at, they work there. So I feel like I'm
taking so many things. It's like you have this
Mecca of the school, and then you have, like,
Main Street, and like that kind of strip of nice
shopping. And then you pretty much go any-
where else outside of it, and it's like you can
see the disparity and the difference between
what you're doing, and where you're living,
and where everybody else is. And you feel like
a visitor, but you also don't want to be one of
those visitors who just, you know, takes and
doesn't have regard for where they're at.

Though Carrie was a temporary citizen of the college town, her experience at the tax site caused her to understand that she is part of the local community. She expressed a desire to broaden her sense of responsibility to people and places that had previously served only as a backdrop for the goings-on of the campus community.

Annie had initially planned to fulfill her servicelearning hours in her hometown but ultimately served at a local tax site instead. Annie found that her experience serving locally helped her reevaluate her relationship to the community. She explained:

Th[is] course has taught me about my college
town in the way only service-learning can - by
getting me outside of my comfort zone and
costing me time... . This community and this
university are shaping me in ways that I can't
yet comprehend, and I owe it to both of them
to give back as much blood, sweat, and tears
as I take.

Annie identified the temporal element of servicelearning as being specific, yet she also began dancing around the spatial in her reflective thinking. Service-learning engaged her relationally with the 
community beyond campus. It moved her from the space of campus to the space of the tax site and forced her to reckon with the community that she encountered there. Her being and existing in space shifted. Credit could not be given solely to the university, for school and society were so intertwined that she was now responsible for and to both.

\section{Discussion}

For Annie and other students in the course, the service-learning experience encouraged an understanding of the power relationships that space requires, in that geography acts as a sorting machine, allowing the privileged to pass through while others remained stuck. This experience of border crossing - both metaphorically and actually in the case of travel to new cities - helped students complicate their understandings of previously opaque borders (Anzaldúa, 1987; Hayes \& Cuban, 1997). Yet an attention to space/place in service-learning can be more local and does not require a physical border crossing (whether that be a railroad track or a nation-state border) but an internal one. In servicelearning, border crossing contains the assumption that you must leave a place to go somewhere else; the act of crossing over helps make inequalities visible.

Yet Clark and Young (2005) expressed concern that merely moving from the campus community into a new space is not enough to prompt an understanding of the power relations that geography encourages. They argued:

\begin{abstract}
Changing places by leaving their campus and working in a homeless shelter should result in a new perspective on issues for the participating students. Without deep authentic engagement, however, standing in this new place could result in nothing more than a 'field trip' to look at the poor.' (p. 73; citing Jones, Gilbride-Brown, \& Gasiorski, 2005)
\end{abstract}

This is why a focus on the power dynamics in familiar spaces is so critical to student learning in service-learning. Simply entering into a new space is not enough to necessitate changed understandings of the way that power relations shape and are shaped by geography (Jacoby, 2015). The politics of the local must be elevated, so that students reckon with the context of the spaces/places they are deeply invested in before and during the servicelearning experience.

What of inequalities that are invisible within your own borders, though? An attention to the space/ place of hometown and college town communities in service-learning demands an action response in a way that border crossing may not in that it points out spatial inequalities occurring in communities that students are already beholden to as citizens. Service-learning helps resist the categorization of campus and home communities (for many though certainly not all, a phenomenon too often glossed over in the service-learning literature) as comfortable spaces while the communities where free tax sites are located are unjustly pushed to the margins.

When students arrive on campus, they often leave behind hometowns enshrined by childhood memories. In college, they invest in their campus communities, but may not similarly steep themselves in the larger college town if it is seen as a temporary space. In this way, the spaces of their hometown and college town are seen as static. Yet Harvey (1993) reminds us that social justice begins when we move through and understand spaces that we once thought of as unchanging, and come to see those spaces instead as places that we must invest in as democratic citizens. Service-learning possesses the potential to demonstrate an inherent inequality in the way that spaces/places are mapped and experienced. Incorporating ways of attentively knowing and being in and of a particular place into the everyday practices of service-learning can help students begin articulating the status quo and engaging in new perspectives and actions that resist inequality. Where students might previously have unconsciously partitioned themselves based on their age, race, and economic class, service-learning asks that they spatialize themselves in new ways that are not based upon cultural and economic ghettoization. Where "local civic culture is [often] fragmented with questions of race, justice, and power," servicelearning offers the opportunity for real partnerships to emerge which encourage students to "grapple with the contradictions and tensions that are the legacies of complex social processes that have evolved in place over time" (Siemers et al., 2015, p. 103). Our understanding of space shapes how we interact in space. Just as Malorie came to reevaluate the downtown area of her hometown after serving at a tax site there, students who are made to pay attention to their assumptions of place begin to engage in those spaces differently. Malorie could no longer write off the people and places she experienced while serving, as they were now firmly a part of her community. Speaking with fellow community members as she worked on their tax returns encouraged an awareness of historical and spatial inequalities that pervaded her hometown. Malorie reconceptualized her role as no longer that of silent and unaware spectator; service-learning prompted her to understand her role as a community member taking action and encouraging dialogue. Her expe- 
rience shows the power that a heightened attention to the spatial can have in investing students in the communities where they serve.

Massey (2005/2015) suggests that space holds meaning-making potential in that an attention to the spatial helps generate new ways of thinking about the social world. As students engage in their hometowns and college towns in new ways, they begin to think differently about the spaces where they serve. Spaces, like the off-campus tax site neighborhood, were once invisible to many of the student participants in the service-learning course, but servicelearning helped students understand the geography of the campus and off-campus communities as entangled. Soja (2010) suggests that both the social and the spatial are imbued with inequalities. Yet engaging in particular spaces/places differently encourages students to resist these inequalities. Service-learning - particularly in communities that students feel they know well - helps locate students differently in space/place, so that alternative ways of being and knowing in community become possible. Beyond making students aware of apparent inequities and shifting perspectives, service-learning enters into students' practices, or patterns of behaving as citizens of their community, helping to reformulate the way that students engage in spaces/ places of service.

Additionally, there is much to be said about the benefits of finding the right community partner with whom a mutual relationship that facilitates both service and learning will thrive (e.g., Enos \& Morton, 2003). This research helps expand the notion of community partner to include the spatial as a community partner in its own right. In this way, the location of the community partnership matters less than the students' relationship to the space/place of service. Whether a service-learning site is located in the college town or beyond, student learning is heightened by attending to students' prior and ongoing mappings of the communities that they serve. Students who prepare taxes at sites in their hometowns or their college town find that the experience causes them to pay added attention to the way that where one is located affects the opportunities available and the possibilities for change, producing particular social relations in particular places.

Despite this, as more students travel out of state to attend college, it is often unrealistic for service-learning placements to take place in students' hometowns. As demonstrated, though, the attachment to place that comes with serving in your hometown can be replicated when service-learning meaningfully involves students in the space/place of their college town. However, the agentic value of meeting community needs as an empowered col- lege student within your own community should not be dismissed. This suggests that community colleges may have a powerful niche within the field of service-learning that has yet to be fully harnessed. Though community college students typically have very different needs than students at four-year institutions, service-learning has already been shown to have a powerful effect on academic success and retention among community college students (e.g., Berger, Burack, Lanspery, \& Duffy, 2015). This research suggests that service-learning may also be particularly beneficial for community college students as a facet of their education which empowers them to be change agents within their own communities.

\section{Limitations}

Because of the limited scale of this qualitative study, the findings should not be generalized as pertinent to all service-learning courses. Rather, faculty interested in pursuing service-learning projects should simply be attentive to the location of the service and the possibility that space/place may affect students' sense of engagement in service-learning and ways of understanding. Because the students were all serving in tax sites throughout the state of Alabama, it is possible that a sense of commitment to their college state impacted their experiences at any location, not just those tax sites where they had the most familiarity.

Further, because of the author's involvement with the service-learning program, the study began after participants received their final course grades. As a consequence, not all of the participants were available for interviews, and the rich data that an ethnographic study would have provided could not be collected. There is also, of course, the possibility that the author's relationships with the participants affected their responses and ways of thinking about their experiences despite the fact that they had already received a grade for the course when the study began.

Finally, one aspect of the study of particular interest to the author is the way that service in one's hometown shapes students' understandings of agency. Because this study concerned students at a four-year state flagship institution, many participants did not have the opportunity to serve in their hometown. Research on the role of service when done exclusively in students' hometowns, as might be the case for community college students, remains a promising avenue for future scholarship. 


\section{Conclusion}

Service-learning's power is not merely that it introduces students to communities beyond campus. Service-learning also has the potential to reintroduce students to communities they know well. Whether their hometown or their college town, service-learning encourages students to question previously crystallized assumptions of a place. Developing new relationships in familiar communities necessarily impacts perspective and can cause a reexamination of practices. Service-learning encourages students to pay attention to inequities in their own community and to be responsible for bringing about a more just community. Service-learning that is steeped in the spatial is affective, especially when students come to understand those spaces/places that they have long known in new, productive ways that demand a remapping of their experiences in their community.

\section{Notes}

This research would not be possible without the support of Professor Stephen Black, who allowed me to study this service-learning course, or without the consent of the participants who willingly shared their experiences in the course with me. Additionally, Dr. Kelly Guyotte was instrumental in guiding me through the qualitative research and publication process.

For the latest iteration of the course syllabus, please contact the author at megan.bailey@ua.edu

\section{References}

Anzaldúa, G. (1987). Borderlands: La frontera (Vol. 3). San Fransisco: Aunt Lute.

Augustine, S. M. (2014). Living in a post-coding world: Analysis as assemblage. Qualitative Inquiry, 20(6), 747-753.

Berger, S., Burack, C., Lanspery, S., \& Duffy, D. (2015). Meaningful connections: Service-learning, peer advocacy, \& student success. Boston: Campus Compact.

Charmaz, K. (2014). Constructing grounded theory ( $2^{\text {nd }}$ ed.). London, United Kingdom: Sage.

Clark, C., \& Young, M. (2005). Changing places: Theorizing space and power dynamics in service-learning. In D. W. Butin (Ed.), Service-learning in higher education (pp. 71-87). New York: Palgrave Macmillan.

Clarke, A. E. (2003). Situational analyses: Grounded theory mapping after the postmodern turn. Symbolic Interaction, 26(4), 553-576.

Curry, J. M., Heffner, G., \& Warners, D. (2002). Environmental service-learning: Social transformation through caring for a particular place. Michigan Journal of Community Service Learning, 9(1), 58-66.
Dacheux, T. (2005). Beyond a world of binaries: My views on service-learning. In D. W. Butin (Ed.), Service-learning in higher education (pp. 67-70). New York: Palgrave Macmillan.

Deleuze. G., \& Guattari, F. (1987). A thousand plateaus: Capitalism and schizophrenia. (B. Massumi, Trans.). Minneapolis, MN: University of Minnesota Press. (Original work published 1980)

Dewey, J. (1900). School and society ( $2^{\text {nd }}$ ed.). Chicago: The University of Chicago Press.

Dewey, J. (1916). Democracy and education. New York: The Free Press.

Ellis, C. (2007). Telling secrets, revealing lives: Relational ethics in research with intimate others. Qualitative Inquiry, 13(1), 3-29.

Enos, S., \& Morton, K. (2003). Developing a theory and practice of campus-community partnerships. In B. Jacoby (Ed.), Building partnerships for servicelearning (pp. 20-41). San Francisco: John Wiley \& Sons.

Gibson-Graham, J. K. (2003). An ethics of the local. Rethinking Marxism, 15(1), 49-74.

Giles, Jr., D. E. \& Eyler, J. (1994). The theoretical roots of service-learning in John Dewey: Toward a theory of service-learning. Michigan Journal of Community Service Learning, 1(1), 77-85.

Gruenewald, D. A. (2003). Foundations of place: A multidisciplinary framework for place-conscious education. American Educational Research Journal, 40(3), 619-654.

Harvey, D. (1993). Social justice and the city. Oxford, United Kingdom: Blackwell. (Original work published 1973)

Hayes, E., \& Cuban, S. (1997). Border pedagogy: A critical framework for service-learning. Michigan Journal of Community Service Learning, 4, 72-80.

Helfenbein, R. (2010). Thinking through scale: Critical geography and curriculum spaces. In E. Malewski (Ed.), Curriculum studies handbook: The next moment (pp. 304-317). New York: Routledge.

Impact America. (2016). SaveFirst. Retrieved from http://impactamerica.com/savefirst/

Jacoby, B. (2015). Service-learning essentials: Questions, answers, and lessons learned. San Francisco: Jossey-Bass.

Jones, S., Gilbridge-Brown, J., \& Gasiorski, A. (2005). Getting inside the "underside" of service-learning: Student resistance and possibilities. In D. W. Butin (Ed.), Service-learning in higher education (pp. 3-24). New York: Palgrave Macmillan.

Kitchin, R., Gleeson, J., \& Dodge, M. (2013). Unfolding mapping practices: A new epistemology for cartography. Transactions of the Institute of British Geographers, 38 (480-496).

Massey, D. (2015). For space. London, United Kingdom: Sage. (Original work published 2005)

Milofsky, C., \& Flack, Jr., W. F. (2005). Service-learning as a source of identity change in Bucknell in Northern Ireland. In D. W. Butin (Ed.), Service-learning in 
higher education (pp. 157-171). New York: Palgrave Macmillan.

Paperson, L. (2010). The postcolonial ghetto: Seeing her shape and his hand. Berkley Review of Education, 1(1), 5-34.

Progressive Policy Institute. (2016). The price of paying taxes II: How paid tax preparer fees are diminishing the Earned Income Tax Credit (EITC). Washington, DC: P. Weinstein \& B. Patten.

Richardson, L., \& St. Pierre, E. A. (2005). Writing: A method of inquiry. In N. K. Denzin \& Y. S. Lincoln (Eds.), The SAGE handbook of qualitative research ( $3^{\text {rd }}$ ed.) (pp. 959-987). Thousand Oaks, CA: Sage.

Robertson, C. (2014, April 7). Tax preparers targeting poor with high fees. The New York Times. Retrieved from http://www.nytimes.com/2014/04/08/us/tax-season-brings-big-refunds-and-preparers-clamoring-fora-slice.html

Shabazz, D. R., \& Cooks, L. M. (2014). The pedagogy of community service-learning discourse: From deficit to asset mapping in the re-envisioning media project. Journal of Community Engagement and Scholarship, 7(1), 71-83.

Siemers, C. K., Harrison, B., Clayton, P. H., \& Stanley, T. A. (2015). Engaging place as partner. Michigan Journal of Community Service Learning, 22(1), 101-104.

Soja, E. (1989). Postmodern geographies: The reassertion of space in critical social theory. London, United Kingdom: Verso.
Soja, E. W. (2010). Seeking spatial justice: Globalization and community. Minneapolis, MN: University of Minnesota Press.

Somerville, M. J. (2010). A place pedagogy for 'global contemporaneity.' Educational Philosophy and Theory, 42(3), 326-344.

Swaminathan, R. (2005). "Whose school is it anyway?" Student voices in an urban classroom. In D. W. Butin (Ed.), Service-learning in higher education (pp. 2543). New York: Palgrave Macmillan.

Taylor, L. H., Jr., \& Helfenbein, R. J. (2009). Mapping everyday: Gender, blackness, and discourse in urban contexts. Educational Studies, 45, 319-329.

\section{Author}

MEGAN SNIDER BAILEY (megan.bailey@ ua.edu) serves as the curriculum development director for The University of Alabama's Center for Ethics and Social Responsibility, where she teaches and facilitates service-learning programs. She is also a doctoral student in Social and Cultural Studies of Education at The University of Alabama and is currently completing her dissertation. Her research interests are service-learning, critical geography, and neocolonization. 